\title{
Prognostic Significance of Gremlin1 (GREM1) Promoter CpG Island Hypermethylation in Clear Cell Renal Cell Carcinoma
}

Iris J.H. van Vlodrop, ${ }^{*}$ Marcella M.L. Baldewijns, ${ }^{*}$ Kim M. Smits, ${ }^{*}$ Leo J. Schouten, ${ }^{\dagger}$ Leander van Neste, ${ }^{\ddagger}$ Wim van Criekinge, ${ }^{\ddagger}$ Hein van Poppel, ${ }^{\S}$ Evelyne Lerut, ${ }^{\mathrm{T}}$

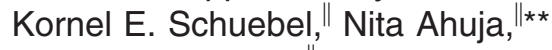
James G. Herman," Adriaan P. de Bruïne, * and Manon van Engeland ${ }^{*}$

\begin{abstract}
From the Departments of Pathology* and Epidemiology, ${ }^{\dagger}$ GROW-School for Oncology and Developmental Biology, Maastricht University Medical Center, Maastricht, The Netherlands; the Department of Molecular Biotechnology, ${ }^{\ddagger}$ Ghent University, Ghent, Belgium; the Departments of Urology and Pathology," University Hospital of Leuven, Leuven, Belgium; and the Division of Cancer Biology"l and Department of Surgery,*** The Sidney Kimmel Comprehensive Cancer Center, The Johns Hopkins University, Baltimore, Maryland
\end{abstract}

Gremlin1 (GREM1), a bone morphogenetic protein antagonist and putative angiogenesis-modulating gene, is silenced by promoter hypermethylation in human malignancies. Here we study GREM1 methylation in clear cell renal cell carcinoma (ccRCC) and its impact on tumor characteristics and clinical outcome. Three GREM1 promoter CpG island regions (i, ii, iii) were analyzed by methylation-specific PCR and/or bisulfite sequencing in ccRCC cell lines and ccRCCs from two independent patient series. Results were correlated with clinicopathological and angiogenic parameters. Bisulfite sequencing of ccRCC cell lines showed GREM1 methylation, associated with absence of GREM1 mRNA. GREM1 methylation prevalence in ccRCCs varied between regions: $55 \%, 24 \%$, and $20 \%$ for regions i, ii, and iii, respectively. GREM1 region iii methylation was associated with increased tumor size $(P=0.02)$, stage $(P=0.013)$, grade $(P=0.04)$, tumor $(P=0.001)$, and endothelial cell $(P=0.0001)$ proliferation and decreased mean vessel density $(P=$ $0.001)$ in a hospital-based ccRCC series $(n=150)$. In univariate analysis, GREM1 region iii methylated cCRCCs had a significant worse survival when compared with unmethylated ccRCCs (hazard ratio $[\mathrm{HR}]=$
$2.35,95 \%$ confidence interval $[\mathrm{CI}]: 1.29$ to 4.28$)$, but not in multivariate analysis (HR $=0.88,95 \%$ CI: 0.45 to 1.74$)$. In a population-based validation series $(n=$ 185), GREM1 region iii methylation was associated with increased Fuhrman grade $(P=0.03)$ and decreased overall survival $(P=0.001)$ in univariate and multivariate analysis (HR $=2.32,95 \%$ CI: 1.52 to 3.53 and $H R=2.27,95 \%$ CI: 1.44 to 3.59 , respectively). The strong correlation between GREM1 region iii promoter methylation and increased malignancy and its correlation with active angiogenesis indicates a role for GREM1 in CCRCC carcinogenesis and tumor angiogenesis. (Am J Pathol 2010, 176:575-584; DOI: 10.2353/ajpath.2010.090442)

Clear cell renal cell carcinoma (ccRCC) accounts for $\approx 75 \%$ of all cases of renal cell cancer, ${ }^{1}$ and is characterized by increased vascularization and an unclear clinical prognosis. Currently, patient performance status, tumor size, nodal and distant metastasis (TNM)-stage, and Fuhrman nuclear grade are the most useful predictors of patient outcome. ${ }^{2}$ However, interest in additional prognostic molecular markers is growing. Inactivation of the von Hippel-Lindau (VHL) gene has been shown to be a common and early event in the carcinogenesis of ccRCC. ${ }^{3-5}$ Fifty to $70 \%$ of ccRCC tumors harbor a VHL mutation, ${ }^{5,6}$ and in $5 \%$ to $20 \%$ of ccRCCs $V H L$ is silenced by promoter $\mathrm{CpG}$ island hypermethylation. ${ }^{7,8}$ Although defective VHL functioning is a key event in the development in both sporadic and hereditary ccRCCs, alterations in the structure or regulation of the VHL gene do not

Supported by the Kootstra-Talent Fellowship Program, Maastricht University Medical Center, Maastricht, The Netherlands.

I.J.H.v.V., M.M.L.B., and K.M.S. contributed equally to this study

Accepted for publication October 27, 2009.

Supplemental material for this article can be found on http://ajp. amjpathol.org

Address reprint requests to Manon van Engeland, Ph.D., Department of Pathology, GROW - School for Oncology and Developmental Biology Maastricht University Medical Center, PO Box 616, 6200 MD Maastricht, The Netherlands. E-mail: manon.van.engeland@mumc.nl. 
appear to be directly associated with tumor cell proliferation and patient prognosis,, 90 suggesting a complex interplay of additional genetic and epigenetic changes that may accumulate during RCC development.

One intriguing candidate gene in this development may be the highly conserved Gremlin1 (GREM1), which we have identified to be expressed on 5'aza-2-deoxycytidine (DAC) treatment in four ccRCC cell lines in a epigenome-wide screen. GREM1 is a secreted glycoprotein that binds and antagonizes bone morphogenetic proteins (BMPs) 2, 4, and 7, thereby preventing the ability of these ligands to interact with their receptors resulting in inhibition of downstream transforming growth factor- $\beta$ signaling. ${ }^{11-13}$ BMPs, the largest subfamily of the transforming growth factor- $\beta$ superfamily, are pleiotropic growth factors serving multiple functions in many cell and tissue types including angiogenesis, proliferation, apoptosis, differentiation, chemotaxis, and extracellular matrix production during development as well as in adult life. ${ }^{14}$ BMPs and BMP-antagonists such as Gremlin1 have been demonstrated in regulating renal development ${ }^{15-18}$ and in the pathogenesis of nephropathy. ${ }^{19-21}$ BMP-independent activities of GREM1 in cancer ${ }^{12,22}$ and angiogene$\mathrm{sis}^{23}$ have also been demonstrated. However, the role of GREM1 in renal cancer pathogenesis and the mechanisms by which GREM1 gene expression is regulated remains incompletely understood.

GREM1 has been identified as one of the targets of Polycomb Repressive Complex 2 (PCR2) subunit protein SUZ12, ${ }^{24}$ which marks repressive chromatin during early stages of embryonic stem cell differentiation. Compared with unmarked stem cell genes, Polycomb group targets have up to 12-fold increased susceptibility to develop cancer-specific promoter $\mathrm{CpG}$ island hypermethylation, ${ }^{25}$ suggesting that epigenetic mechanisms may play a key role in regulating GREM1 expression. Further evidence that this mechanism is important in cancer development has recently been provided by the observations that GREM1 promoter CpG island methylation is prevalent in other tumor types such as gastric, ${ }^{26}$ bladder, and prostate cancer. ${ }^{27}$

The aim of this study was to investigate GREM1 promoter $\mathrm{CpG}$ island methylation and its association with clinicopathological and angiogenesis parameters in ccRCC.

\section{Materials and Methods}

\section{Cell Lines, Study Populations, and Clinical Specimens}

Four ccRCC cell lines (SKRC1, SKRC10, SKRC52, SKRC59), kindly provided by Dr. E. Oosterwijk, Nijmegen Center for Molecular Life Sciences (NCMLS), Nijmegen, The Netherlands, were cultured in RPMI 1640 media (Invitrogen, Breda, the Netherlands) supplemented with $10 \%$ heat-inactivated fetal bovine serum (HyClone, EttenLeur, the Netherlands).

Formalin-fixed and paraffin-embedded tumor samples $(n=150)$ from patients with sporadic ccRCC, treated with radical or partial nephrectomy without any neo-ad- juvant therapy, were collected retrospectively and further referred to as hospital-based series. Of $50 \mathrm{ccRCC}$ patients also histological normal renal tissue was available. In addition, histological normal renal tissue samples (formalin-fixed, paraffin-embedded) of 61 non-RCC patients was collected. All samples were derived from the archives of the Department of Histopathology, University Hospital of Leuven and Department of Pathology, Maastricht University Medical Center. Hematoxylin and eosinstained slides were revised by an experienced genitourinary pathologist to confirm nuclear Fuhrman grading. Tissues were sectioned into $20-\mu \mathrm{m}$ slides, and genomic DNA was isolated and purified using the Puregene DNA purification kit according to the manufacturer's instructions (BIOzym, Landgraaf, The Netherlands). Data of postoperative follow-up (median follow-up 64 months, range 1 to 153 months) at regular intervals by means of physical examination, chest $\mathrm{X}$-ray, abdominal computed tomography, or ultrasound, and when indicated a bone scan was available (for patient characteristics see Table 1).

A second independent population-based validation series of formalin-fixed paraffin embedded cCRCC samples $(n=185)$ was obtained from the Netherlands Cohort Study on diet and cancer (NLCS) ${ }^{28}$ and collected from 51 pathology laboratories throughout the Netherlands with a median follow-up period of 79 months, range 0 to 218 months. This series will be further referred to as population-based series. Tissue collection and DNA isolation have been described in detail elsewhere. ${ }^{29}$ Hematoxylin and eosin-stained slides were revised by an experienced genitourinary pathologist. Information on tumor size and stage was available from the pathological reports and cancer registries. Follow-up was accomplished by record linkage to the municipal population registry and the causes of death registry from Statistics Netherlands ${ }^{10}$ (for patient characteristics see Table 2). This study was approved by the Medical Ethical Committee of the Maastricht University Medical Center.

\section{Drug Treatment and Gene Expression Analysis}

ccRCC cell lines SKRC1, SKRC10, SKRC52, and SKRC59 were treated with 5'aza-2-deoxycytidine (DAC) or Trichostatin A (TSA), which inhibit DNA methylation and histone deacetylases, respectively. $\approx 10 \%$ confluent RCC cells were cultured in RPMI 1640 media containing 10\% fetal bovine serum with $5 \mu \mathrm{mol} / \mathrm{L}$ (DAC; Sigma, St. Louis, MO; stock solution: $1 \mathrm{mmol} / \mathrm{L}$ in PBS) for 96 hours, replacing media and DAC every 24 hours. Cell treatment with 300 nmol/L TSA (Sigma; stock solution: $5 \mathrm{mmol} / \mathrm{L}$ dissolved in ethanol) was performed for 18 hours, starting at $\approx 30 \%$ cell confluency. Mock treated cells were grown in parallel with the DAC treatment by addition of equal volumes of PBS without drugs.

RNA of mock-, DAC-, and TSA-treated cells was isolated using the RNeasy kit (Qiagen, Valencia, CA) according to the manufacturers' instructions. For real-time RT-PCR, $1 \mu \mathrm{g}$ of total RNA was reverse transcribed by using Ready-To-Go You-Prime First-Strand Beads 
Table 1. GREM1 Promoter CpG Island Methylation Associated with Clinical, Histopathological, and Angiogenesis-Related Patient Characteristics (Hospital-Based Series)

\begin{tabular}{|c|c|c|c|c|}
\hline & $\begin{array}{l}\text { All ccRCC } n=150 \\
(100 \%)\end{array}$ & $\begin{array}{c}\text { Methylated GREM1-i } \\
n=77(55 \%)\end{array}$ & $\begin{array}{c}\text { Methylated GREM1-ii } \\
n=33(24 \%)\end{array}$ & $\begin{array}{c}\text { Methylated GREM1-iii } \\
n=28(20 \%)\end{array}$ \\
\hline \multicolumn{5}{|l|}{ Sex } \\
\hline Male, $n(\%)$ & $99(66 \%)$ & $50(65 \%)$ & $22(67 \%)$ & $22(79 \%)$ \\
\hline Female, $n(\%)$ & $51(34 \%)$ & $27(35 \%)$ & $11(33 \%)$ & $6(21 \%)$ \\
\hline$P, \cup$ versus $\mathrm{M}$ & & 0.38 & 0.95 & 0.11 \\
\hline Age, mean & $60.1( \pm 12.1 S D)$ & $60.3( \pm 12.6 \mathrm{SD})$ & $62.3( \pm 11.6 \mathrm{SD})$ & $60.3( \pm 10.4$ SD) \\
\hline$P, U$ versus $\mathrm{M}$ & & 0.80 & 0.33 & 0.96 \\
\hline Tumor size in $\mathrm{cm}$, mean & $6.36( \pm 3.45 \mathrm{SD})$ & $6.91( \pm 3.55 \mathrm{SD})$ & $7.25( \pm 3.54 \mathrm{SD})$ & $7.72( \pm 3.17 \mathrm{SD})$ \\
\hline$P, \cup$ versus $M$ & & 0.01 & 0.08 & 0.02 \\
\hline \multicolumn{5}{|l|}{ Fuhrman grade, $n(\%)$} \\
\hline Grade 1 & $15(10 \%)$ & $5(6 \%)$ & $2(6 \%)$ & $1(4 \%)$ \\
\hline Grade 2 & $72(48 \%)$ & $36(47 \%)$ & $15(46 \%)$ & $11(39 \%)$ \\
\hline Grade 3 & $46(31 \%)$ & $26(34 \%)$ & $10(30 \%)$ & $9(32 \%)$ \\
\hline Grade 4 & $17(11 \%)$ & $10(13 \%)$ & $6(18 \%)$ & $7(25 \%)$ \\
\hline$P, \cup$ versus $\mathrm{M}$ & & 0.54 & 0.61 & 0.04 \\
\hline \multicolumn{5}{|l|}{ Tumor stage, $n(\%)$} \\
\hline Stage 1 & $8(5 \%)$ & $3(4 \%)$ & $0(0 \%)$ & $0(0 \%)$ \\
\hline Stage 2 & $89(60 \%)$ & $42(54 \%)$ & $17(53 \%)$ & $12(43 \%)$ \\
\hline Stage 3 & $30(20 \%)$ & $16(21 \%)$ & $9(28 \%)$ & $7(25 \%)$ \\
\hline Stage 4 & $22(15 \%)$ & $16(21 \%)$ & $6(19 \%)$ & $9(32 \%)$ \\
\hline$P, \cup$ versus $\mathrm{M}$ & & 0.23 & 0.32 & \\
\hline $\mathrm{ECP} \%$, mean & $1.4( \pm 2.17 \mathrm{SD})$ & $1.8( \pm 2.72 \mathrm{SD})$ & $2.5( \pm 3.37 \mathrm{SD})$ & $3.0( \pm 2.97 \mathrm{SD})$ \\
\hline$P, \cup$ versus $M$ & & 0.097 & 0.004 & 0.0001 \\
\hline $\mathrm{TCP} \%$, mean & $6.7( \pm 9.25 \mathrm{SD})$ & $8.2( \pm 11.40 \mathrm{SD})$ & 9.0 ( $\pm 12.70 \mathrm{SD})$ & $12.0( \pm 11.90 \mathrm{SD})$ \\
\hline$P, \cup$ versus $\mathrm{M}$ & & 0.13 & 0.16 & 0.001 \\
\hline MVD per $\mathrm{mm}^{2}$, mean & $197.5( \pm 91.0 \mathrm{SD})$ & $177.4( \pm 81.70 \mathrm{SD})$ & 174.8 ( \pm 89.20 SD $)$ & $152.5( \pm 92.2 \mathrm{SD})$ \\
\hline$P, U$ versus $M$ & & 0.01 & 0.09 & 0.001 \\
\hline
\end{tabular}

(Amersham Biosciences/GE Health care, Piscataway, NJ) with addition of random hexamers $(0.2 \mu \mathrm{g}$ per reaction). RNA of a subset of the hospital-based series primary ccRCCs and normal renal tissue from noncancerous pa-

Table 2. GREM1 Promoter CpG Island Methylation Associated with Clinical, Histopathological, and Angiogenesis-Related Patient Characteristics (Population-Based Series)

\begin{tabular}{|c|c|c|}
\hline & $\begin{array}{c}\text { All ccRCC } \\
n=185 \\
(100 \%)\end{array}$ & $\begin{array}{c}\text { Methylated } \\
\text { GREM1-iii } \\
n=68(40 \%)\end{array}$ \\
\hline \multicolumn{3}{|l|}{ Sex } \\
\hline Male, $n(\%)$ & $108(59 \%)$ & $44(65 \%)$ \\
\hline Female, $n(\%)$ & $74(41 \%)$ & $24(35 \%)$ \\
\hline$P, U$ versus $M$ & & 0.32 \\
\hline $\begin{array}{l}\text { Age, mean } \\
P, \cup \text { versus } M\end{array}$ & $67.4( \pm 4.7 \mathrm{SD})$ & $\begin{array}{c}67.2( \pm 5.2 \mathrm{SD}) \\
0.49\end{array}$ \\
\hline $\begin{array}{l}\text { Tumor size in } \mathrm{cm} \text {, } \\
\text { mean }\end{array}$ & $7.9( \pm 3.9 \mathrm{SD})$ & $7.5( \pm 3.17 \mathrm{SD})$ \\
\hline$P, U$ versus $M$ & & 0.16 \\
\hline \multicolumn{3}{|c|}{ Fuhrman grade, $n(\%)$} \\
\hline Grade 1 & 42 (23\%) & $10(15 \%)$ \\
\hline Grade 2 & $66(36 \%)$ & 22 (32\%) \\
\hline Grade 3 & $47(26 \%)$ & $23(34 \%)$ \\
\hline Grade 4 & $27(15 \%)$ & $13(19 \%)$ \\
\hline$P, U$ versus $M$ & & 0.03 \\
\hline \multicolumn{3}{|l|}{ Tumor stage, $n(\%)$} \\
\hline Stage 1 & $4(2 \%)$ & $0(0 \%)$ \\
\hline Stage 2 & $81(45 \%)$ & $27(40 \%)$ \\
\hline Stage 3 & $63(35 \%)$ & $23(34 \%)$ \\
\hline Stage 4 & 32 (18\%) & $18(26 \%)$ \\
\hline$P, \cup$ versus $M$ & & 0.08 \\
\hline
\end{tabular}

Tumor stage based on International Union against Cancer (UICC) TNM classification of malignant tumors, fourth, fully revised edition, 1987.

$P$ indicates $P$ value for comparison of methylated and unmethylated cases. tients was isolated from frozen tissue using the GenElute Total RNA kit (Sigma) according to the manufacturers' instructions. For real-time RT-PCR, $1 \mu \mathrm{g}$ of total RNA was reverse transcribed by using the iScript cDNA synthesis kit (Bio-Rad, Veenendaal, the Netherlands). (Primer sequences and PCR conditions are provided in Table 3.)

\section{GREM1 Methylation-Specific PCR and Bisulfite Sequencing}

The highly conserved human GREM1 gene (accession number NM_013372) is located on chromosome 15q13q15. For CpG island prediction, EMBOSS (http://emboss. sourceforge.net/) software using the following criteria (Obs/ Exp: 0.6, MinPC: 50, length: 200) was used. This resulted in the identification of three closely located CpG islands from $-650 \mathrm{bp}$ to $+1671 \mathrm{bp}$ relative to the transcription start site (TSS) (Figure 1A), which will be further considered as one island. To cover a large part of the promoter region for GREM1 methylation analysis, three different nested methylation-specific PCR (MSP) primer sets (GREM1 region $\mathrm{i}$, region ii, and region iii) were designed (see Figure $1 \mathrm{~A}$ ). GREM1 promoter $\mathrm{CpG}$ island methylation was determined by chemical modification of genomic DNA with sodium bisulfite and subsequent MSP as described in detail elsewhere. ${ }^{30-32}$ In brief, 500 ng of DNA was modified by sodium bisulfite using the EZ DNA methylation kit (Zymo Research, Orange, $C A$ ) according to the manufacturer's instruction. To facilitate MSP analysis on DNA retrieved from formalin-fixed paraffin-embedded tissue, DNA was first amplified with flanking PCR primers that amplify bisulfite-modified DNA but do not preferentially amplify methylated or unmethylated 
Table 3. PCR Primers and Conditions for GREM1

\begin{tabular}{|c|c|c|c|c|c|}
\hline Method & Forward & Reverse & $\begin{array}{l}\mathrm{Tm} \\
\left({ }^{\circ} \mathrm{C}\right)\end{array}$ & $\begin{array}{l}\text { Cycles } \\
\text { (n) }\end{array}$ & $\begin{array}{l}\text { Length } \\
\text { (bp) }\end{array}$ \\
\hline $\begin{array}{l}\text { RT } \\
\text { MSP i }\end{array}$ & \multicolumn{5}{|c|}{ 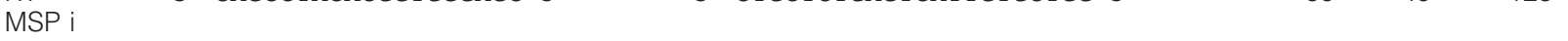 } \\
\hline $\mathrm{Fl}$ & 5'-TGGYGATAGGTTTTTGTTGG-3' & 5'-CCСCTCTAAAAAAAACRAAACTA-3' & 56 & 35 & 156 \\
\hline$U$ & 5'-GTTTTTGTTGGTGGTTAGTGAGTTT-3' & 5'-AACAAAACTACAAAATACTCTAATCAAACA-3' & 62 & 30 & 134 \\
\hline $\mathrm{M}$ & 5'-TGTTGGCGGTTAGCGAGTTC-3' & 5'-GAAACTACGAAATACTCTAATCGAACG-3' & 62 & 30 & 126 \\
\hline \multicolumn{6}{|l|}{ MSP ii } \\
\hline $\mathrm{FI}$ & 5'-TTTTGGGGTGATTTTTTTTAGT-3' & $5^{\prime}-\mathrm{CACCCCTCCTACTTCCCC-3^{ \prime }}$ & 56 & 35 & 96 \\
\hline U & 5'-GTGATTTTTTTTAGTTGGTTTGGGT-3' & $5^{\prime}$-АССССТССТАСТTCСССАСА-3' & 64 & 35 & 88 \\
\hline M & $5^{\prime}$-ATTTTTTTTAGTCGGTTCGGGC-3' & $5^{\prime}-$ CCCTCCTACTTCCCCGCG-3' & 64 & 35 & 83 \\
\hline \multicolumn{6}{|c|}{ 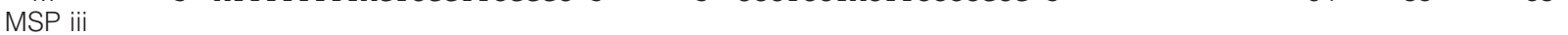 } \\
\hline $\mathrm{Fl}$ & 5'-GGGGTTTTTTTTGTTGAGGT-3' & $5^{\prime}-\mathrm{CTACTACCACCAACACCAAAAAC-3^{ \prime }}$ & 56 & 35 & 161 \\
\hline$U$ & 5'-TTTTTTTGTTGAGGTTGTGGATATT-3' & 5'-CAAAAACATATTCAAAAACCTCCA-3' & 65 & 25 & 140 \\
\hline M & 5'-TTTGTTGAGGTCGCGGATATC-3' & $5^{\prime}-$ AAAACGTATTCGAAAACCTCCG-3' & 65 & 25 & 134 \\
\hline BSseq i & 5'-TGGYGATAGGTTTTTGTTGG-3' & 5'-CCCAAATCTAAACTTTCCCTATC-3' & 60 & 35 & 279 \\
\hline BSseq ii & 5'-GATAGGGAAAGTTTAGATTTGGG- $3^{\prime}$ & $5^{\prime}$-САССССТССТАСТТСССС-3' & 64 & 35 & 222 \\
\hline BSseg iii & 5'-AGGGTYGTAAATTAATTTAGGATT-3' & 5'-CTACTACCACCAACACCAAAAAC - $3^{\prime}$ & 60 & 40 & 268 \\
\hline BSseq TSS & 5'-GGYGTTTGGTTAATGGAGAGG-3' & 5'-CRCCCACTCACATCCCTACC-3' & 62 & 35 & 279 \\
\hline
\end{tabular}

RT indicates real-time reverse transcriptase PCR; MSP i, ii, iii, methylation-specific PCR GREM1-region i, GREM1-region ii, GREM1-region iii, respectively; M, methylation sensitive primers; U, nonmethylation sensitive primers; BSseq i, ii, iii, TSS, bisulfite sequencing GREM1-region i, ii, iii, and around transcription start site.

DNA. The resulting fragment was used as a template for the MSP reaction. GREM1 region i, region ii, and region iii methylation was analyzed on the hospital-based series of cCRCCs. On the population-based series, GREM1 region iii MSP was performed. All PCRs were performed with controls for unmethylated alleles (DNA from normal lymphocytes or DNA from human umbilical vein endothelial cells, methylated alleles [normal lymphocyte DNA treated in vitro with SssI methyltransferase (New England Biolabs, Leusden, the Netherlands)], and a control without DNA. Primer sequences and PCR conditions are provided in Table 3. Ten $\mu$ of each MSP reaction was directly loaded onto $2 \%$ agarose gels containing GelStar Nucleic Acid Gel Stain (Cambrex, NJ), and visualized under UV illumination. The methylation status of the hospital-based ccRCC series was successfully obtained in $93 \%$ to $95 \%$ (138 to 141 of 149 , one sample failed to provide a sufficient amount of DNA), dependent on the primer set used, and in 91\% (168 of 185) of the population-based series. To assess reproducibility, MSP reactions have been performed in duplicate or triplicate starting from DNA amplification with flanking PCR primers. The reproducibility was $82 \%, 95 \%$, and $97 \%$ for primer set i, ii, and iii, respectively in the hospital-based series and $84 \%$ in the population-based series. Nonconcordant MSP results were analyzed a third time, and a two of three concordance was used as end result.

For bisulfite sequencing, PCR products were cloned using the TOPO TA cloning kit (Invitrogen, Breda, the Netherlands), single colonies were sequenced using M13 primer, BigDye Terminator v1.1 Cycle Sequencing Kit in accordance to the manufacturer's instruction. Primer sequences and PCR conditions are provided in Table 3.

A
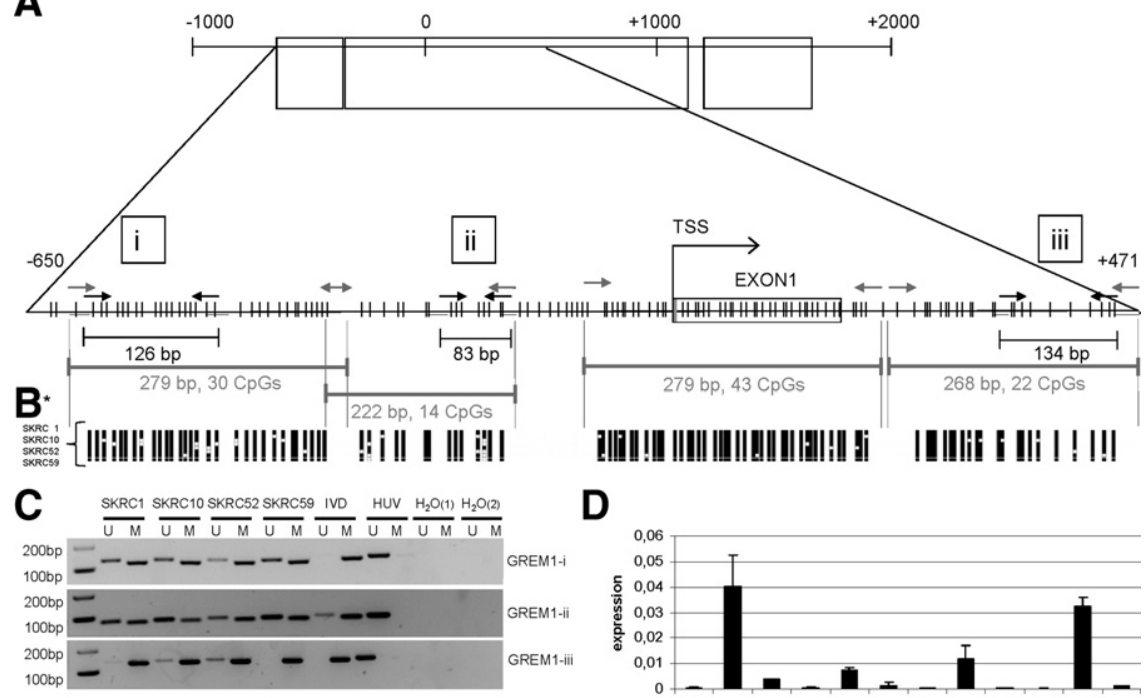

* representative clones for SKRC1, SKRC10, SKRC52, and fogion i, ii, TSS, and iii
D

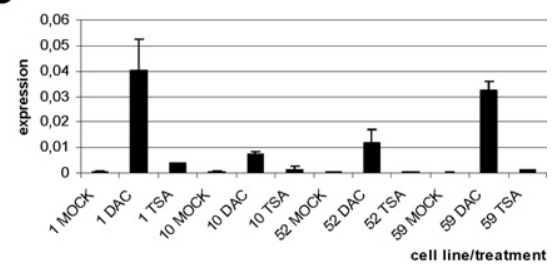

Figure 1. GREM1 promoter $\mathrm{CPG}$ island, methylation analyses, and mRNA expression in ccRCC cell lines. GREM1 putative promoter CpG island relative to the transcription start site (TSS), including the locations of BSseq primer sets (i, ii, TSS, and iii; grey arrows: sequence primer locations) and MSP primer sets i, ii, and iii (underlined: flank PCR primer locations, black arrows: methylation specific PCR primer location, respectively) (A) with representive BSseq (B), MSP, asterisk represents clones for bisulfite sequencing of the cell lines SKRC1, SKRC10, SKRC52, and SKRC59 for region i, ii, TSS and iii. (C), and mRNA expression (D) results of ccRCC cell lines SKRC1, SKRC10, SKRC52, SKRC59. mRNA expression data resulted after three independent experiments. Open/closed squares indicate unmethylated/ methylated CpGs. U indicates unmethylated product; M, methylated product; IVD, methylation positive control; HUV, methylation negative control; H2O(1), Flank PCR control without DNA; H2O(2), MSP control without DNA; DAC, 5'aza-2-deoxycytidine; TSA, Trichostatin A. 


\section{Assessment of Angiogenesis and Tumor Parameters}

Quantification of micro vessel density (MVD), endothelial cell proliferation (ECP), and tumor cell proliferation (TCP) in the hospital-based series has been described in detail elsewhere. ${ }^{33}$

Briefly, CD34/Ki-67 double immunohistochemical staining ${ }^{34}$ was used to analyze MVD, ECP, and TCP. One tissue slide was analyzed per tumor. For assessment of the vascular density within a tumor tissue slide, one hotspot (most vascularized microscopic field) was selected and four areas were chosen randomly. Vessel counts were performed at $\times 200$ magnification using an optical grid. The presence of a vascular lumen was not necessary to identify a micro vessel. MVD was expressed as vessels per $\mathrm{mm}^{2}$. Next, a total number of at least 500 intratumoral endothelial cells and 500 tumor cells were evaluated in consecutive fields at a $\times 400$ magnification and the fractions of proliferating endothelial cells (ECP\%) and tumor cells (TCP\%) were assessed. ECP\% and $\mathrm{TCP} \%$ were calculated according to the following formulas: ECP\% = (the number of endothelial cells with Ki-67stained nuclei/total number of endothelial cells evaluated) $\times 100 ; \mathrm{TCP} \%=$ (the number of tumor cells with Ki-67-stained nuclei/total number of tumor cells evaluated) $\times 100$.

\section{Statistical Analysis}

Cause-specific survival was defined as the time from cancer diagnosis until renal cancer-related death or until the end of follow-up. Differences in clinicopathological and angiogenesis characteristics between ccRCCs with and without GREM1 promoter CpG island methylation were evaluated with the Student $t$ tests and Pearson $\chi^{2}$ tests. Kaplan-Meier analyses and log-rank tests were used to estimate the overall influence of GREM1 promoter $\mathrm{CpG}$ island methylation on cause-specific survival. HRs and corresponding $95 \% \mathrm{Cl}$ were assessed by use of Cox proportional hazard models. Factors were considered possible confounders if they were known prognostic factors for renal cancer and influenced the crude HR. Possible confounders that were included in the model for both series were sex, age at diagnosis, cancer stage, tumor size, and nuclear grade. The proportional hazard assumption was tested using the Schoenfeld residuals. Analyses were performed by use of the statistical package STATA 9.0. All reported $P$ values are two-sided, and $P$ values $\leq 0.05$ were considered statistically significant.

\section{Results}

\section{Promoter CpG Island Methylation and Down-Regulation of GREM1 mRNA Expression in ccRCC Cell Lines}

GREM1 promoter CpG island methylation and mRNA expression were analyzed by MSP and real time RT-PCR in the cCRCC cell lines SKRC1, SKRC10, SKRC52, SKRC59. All four cell lines were heavily methylated at region $\mathrm{i}$, region ii, and region iii of the $\mathrm{CpG}$ island (Figure 1C). MSP data were confirmed by bisulfite sequencing of

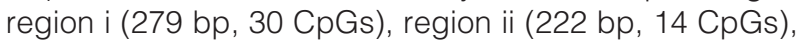
and region iii (268 bp, $22 \mathrm{CpGs).} \mathrm{Methylation} \mathrm{at} \mathrm{the}$ transcription start site (TSS; 279 bp, 43 CpGs) was assessed by bisulfite sequencing (Figure 1B). As shown in Figure 1D, little or no mRNA expression is observed in SKRC1, SKRC10, SKRC52, and SKRC59. mRNA expression could be induced in all four cell lines by DAC but not, or to a much lesser extent, by TSA.

\section{GREM1 Promoter CpG Island Hypermethylation in ccRCCs Varies at Different Regions in the Promoter CpG Island}

To analyze GREM1 promoter CpG island methylation in primary ccRCCs, a hospital-based series of ccRCCs was analyzed for methylation at three regions in the promoter. $63 \%(93 / 147,3$ samples did not yield a MSP result in region $\mathrm{i}$, region $\mathrm{ii}$, and region $\mathrm{iii}$ ) of the ccRCCs showed methylation of one or more of the three analyzed regions. A decrease of methylation prevalence was seen more downstream in the analyzed area, with 55\% (77/141) methylation for region i ( -648 to -462$), 24 \%$ (33/139) for region ii $(-236$ to -140$)$, and $20 \%(28 / 138)$ for region iii $(+311$ to +472 ; Table 1$)$. Methylation in matching histological normal renal tissues was observed in 28\% (14/50), $16 \%(8 / 50)$, and 10\% (5/50) for region i, ii, and iii, respectively (data not shown). In histological normal renal tissues from noncancer patients, 0 to $16 \%$ methylation was observed in the sub regions (region $\mathrm{i}$ : $7 / 61$, region ii: 10/61, region iii: 0/61), data not shown.

\section{GREM1 Promoter CpG Island Methylation at Region iii Is Associated with Increased Tumor Size, Tumor Grade and Stage, Angiogenesis, and Poor Prognosis}

Next, we studied the association of GREM1 promoter $\mathrm{CpG}$ island methylation and patient characteristics and clinical outcome. In Table 1, patient and tumor characteristics for the $150 \mathrm{ccRCC}$ cases included in the GREM1 promoter hypermethylation analyses are presented; methylated cases were stratified by methylation site. No differences among methylated and unmethylated cases were observed in the distribution of age and sex ( $P$ values $>0.05$, see Table 1$)$. Consistent with the number of methylated cases, associations between GREM1 promoter methylation and clinical-, histopathological-, and angiogenesis-related patient characteristics are dependent on the region of methylation. GREM1 region i methylation was associated with tumor size $(P=0.01)$ and $\operatorname{MVD}(P=0.01)$. The median overall survival $(O S)$ and metastasis free survival (MFS) for unmethylated versus methylated cases at region i is 60.5 (1 to 143) versus 64.5 (range, 2 to 153) and 58.5 (1 to 143) versus 41 months (0 to 143), respectively. The Kaplan-Meier curve for GREM1 

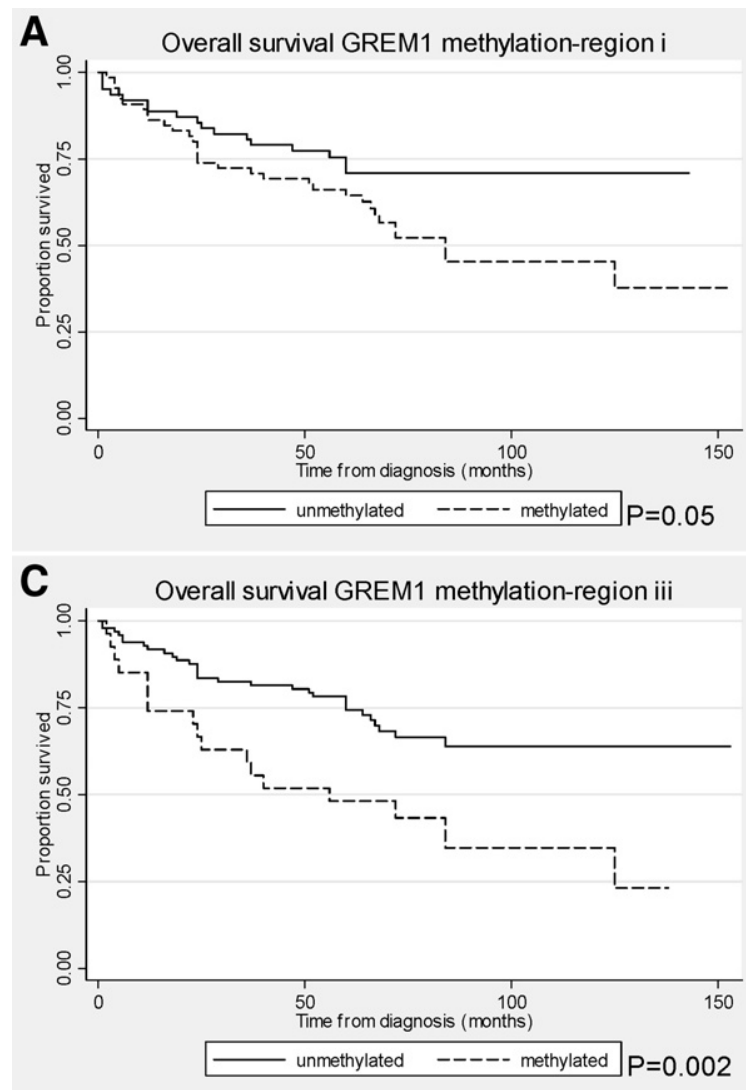
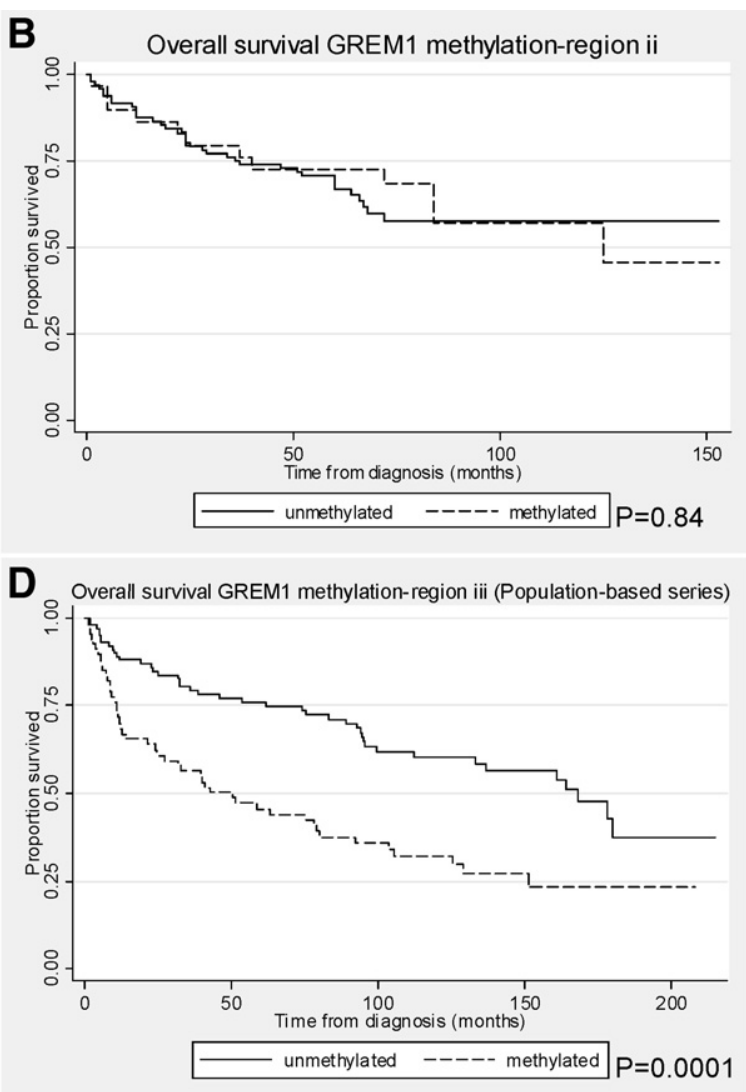

Figure 2. Overall cause-specific survival curves for ccRCC patients according to GREM1 promoter CpG island methylation at region i (A), ii (B), and iii (C and $\mathbf{D})$, with $\mathbf{A}, \mathbf{B}$, and $\mathbf{C}$ for patients of the hospital-based series and $\mathbf{D}$ for patients of the population-based series.

region i methylation (Figure $2 \mathrm{~A}$ ) shows a borderline statistically significant difference in OS for methylated and unmethylated cases (log-rank, $P=0.05$ log-rank MFS, $P=0.73$, data not shown). Age- and sex-adjusted Cox proportional hazard analyses show a statistically significant association between GREM1 region i methylation and $\mathrm{OS}\left(\mathrm{HR}_{\mathrm{i}}=1.84 ; 95 \% \mathrm{Cl}, 1.02\right.$ to 3.32, but not for MFS $\left(\mathrm{HR}_{\mathrm{i}}=1.08 ; 95 \% \mathrm{Cl}, 0.76\right.$ to 1.54$)$. Multivariate analyses, however, show no association between GREM1 region i and OS or MFS $\left(\mathrm{HR}_{\mathrm{i}}=0.66 ; 95 \% \mathrm{Cl}, 0.33\right.$ to 1.33 , and $\mathrm{HR}_{\mathrm{i}}=0.82 ; 95 \% \mathrm{Cl}, 0.55$ to 1.21 , respectively).

GREM1 region ii methylation was only significantly associated with ECP $(P=0.004)$. The median OS and MFS for unmethylated versus methylated cases at region ii is 60.5 (1 to 153) versus 76 (range, 1 to 153) and 56 (1 to 153) versus 60 months (0 to 153), respectively. Figure $2 B$ shows the Kaplan-Meier curve for GREM1-region ii; no difference was observed between methylated and unmethylated cases (log-rank $P=0.84$, log-rank MFS, $P=$ 0.15 , data not shown). Methylation of GREM1-region ii was not significantly associated with OS or MFS in the age- and sex-adjusted Cox regression analyses $\left(\mathrm{HR}[\mathrm{OS}]_{\mathrm{ii}}=0.93\right.$; $95 \% \mathrm{Cl}, 0.48$ to 1.80 , and $\mathrm{HR}[\mathrm{MFS}]_{\mathrm{ii}}=0.74 ; 95 \% \mathrm{Cl}, 0.49$ to 1.12$)$ nor in the multivariate analyses $\left(\mathrm{HR}[\mathrm{OS})_{\mathrm{ii}}=0.55\right.$; $95 \% \mathrm{Cl}, 0.26$ to 1.18 , and HR[MFS $]_{\mathrm{ii}}=0.56 ; 95 \% \mathrm{Cl}, 0.36$ to 0.87$]$.

In contrast, ccRCCs methylated at region iii are statistically significantly larger in tumor size $(P=0.02)$ and have a statistically significant higher tumor grade $(P=$ 0.04), tumor stage $(P=0.013)$, ECP ratio $(P=0.0001)$, and TCP ratio $(P=0.001)$, as compared with tumors unmethylated at region iii, and methylated cases have a lower MVD (per $\mathrm{mm}^{2}, P=0.001$ ). The median OS and MFS for unmethylated versus methylated cases at region iii is 65.5 (1 to 153) versus 56 (range, 2 to 138), and 60 (1 to 153) versus 23 months (0 to 138), respectively. Figure $2 \mathrm{C}$ shows the Kaplan-Meier curve for cause-specific survival and GREM1 region iii methylation, and methylated cases had a statistically significant worse survival as compared with unmethylated cases (log-rank $P=0.002$, log-rank MFS $P=0.05$, data not shown). Age- and sexadjusted Cox proportional hazard analyses also show a significant association between GREM1 region iii methylation and $\mathrm{OS}(\mathrm{HR}=2.35 ; 95 \% \mathrm{Cl}$ : 1.29 to 4.28$)$; the association with MFS was borderline significant (HR = 1.54; 95\% Cl: 0.99 to 2.39). However, in multivariate analyses adjusted for age, sex, grade, stage, and tumor size, GREM1 region iii methylation does not seem to be an independent prognostic factor: $\operatorname{HR}(O S)=$ $0.88,95 \% \mathrm{Cl}: 0.45$ to 1.74 , and $\mathrm{HR}(\mathrm{MFS})=1.04,95 \%$ $\mathrm{Cl}: 0.65$ to 1.68 .

Because GREM1 promoter CpG island methylation at region iii was most cancer-specific and because of the result obtained for this region in the hospital-based series, we next aimed to validate the results obtained for GREM1 region iii, in an independent population-based 
series of ccRCC (Table 2). Age and sex were equally distributed among the methylated and unmethylated cases in this series, ( $P$ values $>0.05$, see Table 2$)$. $40 \%$ (68 of 168) of the ccRCCs with GREM1 region iii MSP results were methylated and methylated tumors more often had a higher tumor grade $(P=0.03)$ as compared with unmethylated tumors. A similar trend was seen for tumor stage $(P=0.08)$. The median OS for unmethylated versus methylated cases at region iii is 96 ( 1 to 218) versus 42 (range, 1 to 212), respectively. Figure 2D shows the Kaplan-Meier curve for cause-specific survival and GREM1 region iii methylation, and methylated cases had a statistically significant worse survival as compared with unmethylated cases (log-rank test $P=0.0001$ ). Cox regression analyses also showed a statistically significant association between methylation and OS with an ageand sex-adjusted HR of 2.32 (95\% Cl: 1.52 to 3.53 ) and a multivariate HR of 2.27 (95\% Cl: 1.44 to 3.59 , adjusted for age and sex, grade, stage, and size).

\section{Discussion}

Epigenetic silencing of GREM1 by promoter CpG island methylation is present in CcRCC cell lines and can be reversed by inhibiting DNA methyltransferases, indicating that DNA methylation is involved in GREM1 silencing. We have also shown an association between GREM1 promoter $\mathrm{CPG}$ island hypermethylation and increased malignancy/angiogenesis in primary ccRCCs, whereas methylation in histological normal renal tissue is an infrequent event.

Interestingly, GREM1 promoter CpG island methylation in primary ccRCCs varies within the $\mathrm{CpG}$ island, with frequencies of $55 \%, 24 \%$, and $20 \%$ for region i, region ii, and region iii, respectively. We showed that within one $\mathrm{CpG}$ island, CpG methylation at loci only a few hundred bp apart can differ strongly. As previously shown for $h M L H 1$ in colorectal cancer, methylation-associated transcriptional silencing can occur in a region-specific manner, ${ }^{35}$ indicating that also clinical effects may be methylation-region specific. This observation emphasizes that the location of $\mathrm{CpG}$ dinucleotides to be analyzed and with this, MSP primer location and design, can influence the observed methylation prevalence and clinical association. $^{36}$

Analyses of clinicopathological characteristics revealed that significant differences between GREM1 methylated and unmethylated ccRCCs are also dependent on the region analyzed. Only for the most downstream region (iii), $\mathrm{CpG}$ methylation was statistically significant associated with increased malignancy (ie, larger tumors, higher tumor grade and stage, and a worse prognosis). These data suggest that the effect of GREM1 promoter $\mathrm{CpG}$ island methylation on ccRCC biology depends on the region methylated within the $\mathrm{CpG}$ island. Whether GREM1 promoter CpG island methylation initiates at region $i$ and then spreads downstream toward the TSS and region iii or starts in region iii and then retroverts toward region i cannot be deduced from these data.

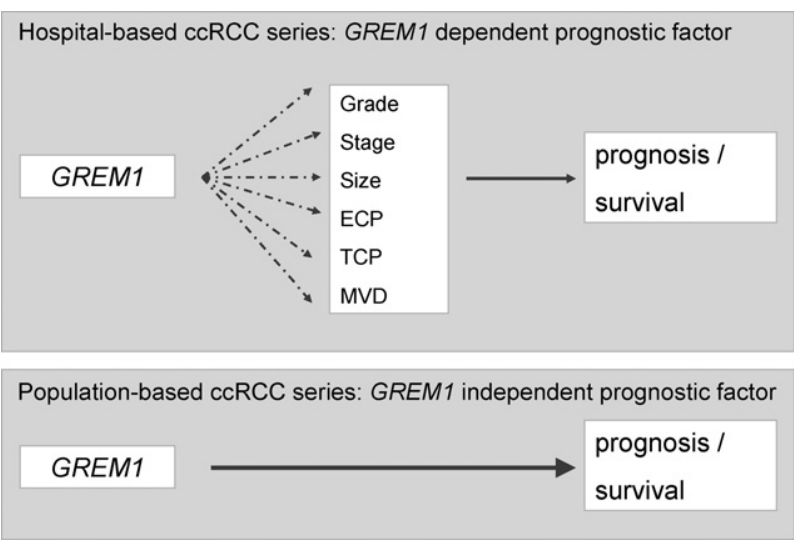

Figure 3. Prognostic significance of GREM1 promoter CPG island methylation in hospital-based and population-based cCRCC patient series.

The second series is derived from the populationbased prospective Netherlands Cohort Study, and therefore appropriate for validation of the results. This series confirmed the associations between region iii methylation and tumor grade and prognosis, which were found in the hospital-based series. In addition, this validation points to GREM1 as a gene independently influencing the progression of ccRCCs when methylated at region iii (Figure 3, lower panel), which was not found in the hospital-based series to the same extent (Figure 3, upper panel). Possible differences between the two ccRCC series were not apparent but could perhaps account for this observation. Nevertheless, both series do indicate a significant effect of GREM1 region iii methylation on increased malignant behavior and a worse prognosis of cCRCC.

Our data also show that GREM1 region iii methylation is significantly associated with increased ECP, TCP, and lower MVD, suggesting that GREM1 silencing promotes active angiogenesis, pointing to GREM1 as an antiangiogenesis factor. Similar observations showing that BMP2 and BMP4 exert angiogenic activity, which may increase with inactivation of the BMP-antagonist GREM1, have been reported. ${ }^{37-39}$ However, a recent study by Stabile et al indicated a BMP-independent proangiogenic function of GREM1 by showing GREM1 expression in human lung tumor endothelium and binding of GREM1 to the endothelial cell surface thereby activating intracellular signaling and cell motility. ${ }^{23}$ An angiogenic role of GREM1 may be tissue-specific and/or dose-dependent. ECP also may be indirectly influenced by GREM1 through its strong correlation with TCP $(\mathrm{Rho}=0.82, P<0.001)$. Moreover, during tumor progression, cumulative genetic/epigenetic events can activate additional angiogenic growth factors, resulting in an increased tumor driven angiogenesis. Additionally, GREM1 promoter CpG island methylation may affect maturation of intratumoral blood vessels in CCRCC, as Maciel et al reported induction of vascular smooth muscle cell proliferation and migration by Gremlin. ${ }^{40}$ This is supported by the fact that CCRCC with high ECP, representing high grade cCRCC, are shown to be characterized by a less stabilized and less mature vasculature. ${ }^{33}$ Therefore, GREM1 inactivation may impede tumor vessel maturation, as observed in high-grade tumors, in 
which less differentiated vessels provide an easier access for cancer cells to the circulation.

Except for sclerostin domain-containing-1 (SOSTDC1), another BMP antagonist that suppresses proliferation of RCC cells and is down-regulated in RCC, ${ }^{41}$ no other BMP antagonists have previously been implicated in RCC. GREM1 has been shown to be down-regulated in several tumor cell lines (ie, neuroblastoma, fibrosarcoma, colon adenocarcinoma, breast carcinoma), suggesting a tumor suppressor function. ${ }^{22,42}$ However, the role of GREM1 in renal carcinogenesis has not yet been elucidated. Silencing of GREM1 by promoter CpG island methylation may play a role in carcinogenesis both by affecting cell cycle and by upregulation of BMP signaling. Earlier studies have linked BMPs and BMP receptors (BMP-RI and BMPRII) to cancer. ${ }^{43-45}$ Biological responses to BMP are cell type-specific and divergent effects with both oncogenic and tumor suppressor activities have been described. ${ }^{44}$ Despite the progress achieved in delineating the functional significance of BMP pathways in carcinogenesis in general during the last decade, ${ }^{46-50}$ little is known about the importance of BMP signaling in RCC.

To learn more about the role of GREM1 and the consequence of silencing GREM1 in CCRCC cancer, the relationship between promoter $\mathrm{CpG}$ island methylation and gene and protein expression needs to be explored. In this study GREM1 promoter CpG island methylation and mRNA expression did not correlate (see supplemental Figure S1, at http://ajp.amjpathol.org). Several explanations can explain these results. First, overall the basal expression level of GREM1 in normal kidney is very low, an observation that has been reported for other (candidate) tumor suppressor genes/biomarkers as well $\left(T P 53^{51}, V I M^{52}\right)$, indicating that the regulation of expression of important cancer-associated genes is complex. Our data are in agreement with the literature consensus on GREM1 expression levels in normal adult renal tissue, which seems to be very low or undetectable ${ }^{53-56}$ (see also supplemental Figure S1, at http://ajp.amjpathol.org). An explanation for this observation could be that GREM1 is a gene involved in embryogenesis. Many embryologically expressed genes regulate morphogenesis and then become quiescent, which could explain the absence of GREM1 expression in adult normal renal tissue. ${ }^{57}$ It is increasingly being appreciated that some developmental genes are reactivated in the adult in diseased tissues. Gremlin expression in the diabetic glomerulus ${ }^{53,54}$ serves to illustrate the complexities and opportunities posed by this emerging paradigm. ${ }^{57}$ These literature observations as well as our own data indicate that analyzing epigenetic silencing of GREM1 in cancer tissue as compared with normal epithelial tissue is complex.

An additional complicating factor is the observation that the Gremlin protein belongs to the Dan family of secreted glycosylated proteins ${ }^{13,58}$ and that expression is predominantly observed in the stromal counterpart of other cancers types (skin, lung, esophagus, pancreas, breast, bladder, colon). ${ }^{23,56}$ This complicates studying the correlation between epithelial promoter methylation and epithelial RNA and protein expression. At the same time, Sun et al reported tissue-specific intracellular inter- action between Gremlin and BMP4, ${ }^{59}$ which indicates again the (micro)environment dependency of the expression and actions of Gremlin1.

In conclusion, our results indicate that promoter $\mathrm{CpG}$ island methylation of GREM1 has an impact on the biology and outcome of this type of cancer. Notably, GREM1 region iii promoter $\mathrm{CpG}$ island hypermethylation appears to be independently associated with aggressive tumor behavior and increased angiogenesis and therefore could be a candidate tumor suppressor gene and interesting prognostic biomarker in ccRCC. Probably, this prognostic effect is mediated through an increase in TCP and ECP. However, the exact mechanism of GREM1 inactivation and its relation to tumor progression as well as its role in angiogenesis need to be further clarified. In addition, further studies are needed to explore whether GREM1 promoter CpG island methylation can also be detected in urine or serum samples for use as a possible noninvasive marker for aggressive ccRCC.

\section{Acknowledgments}

We thank Dr. Egbert Oosterwijk from the Nijmegen Center for Molecular Life Sciences (NCMLS), Radboud University Nijmegen Medical Center (RUNMC), Nijmegen, The Netherlands for providing the renal carcinoma cell lines. We thank Sean Smith for technical support.

\section{References}

1. Kovacs G, Akhtar M, Beckwith BJ, Bugert P, Cooper CS, Delahunt B Eble JN, Fleming S, Ljungberg B, Medeiros LJ, Moch H, Reuter VE, Ritz E, Roos G, Schmidt D, Srigley JR, Storkel S, van den Berg E, Zbar B: The Heidelberg classification of renal cell tumours. J Pathol 1997, 183:131-133

2. Gelb AB: Renal cell carcinoma: current prognostic factors. Union Internationale Contre le Cancer (UICC) and the American Joint Committee on Cancer (AJCC). Cancer 1997, 80:981-986

3. Kaelin WG Jr: The von Hippel-Lindau tumor suppressor gene and kidney cancer. Clin Cancer Res 2004, 10:6290S-6295S

4. van Dijk BA, Schouten LJ, Oosterwijk E, Hulsbergen-van de Kaa CA, Kiemeney LA, Goldbohm RA, Schalken JA, van den Brandt PA: Cigarette smoking, von Hippel-Lindau gene mutations and sporadic renal cell carcinoma. Br J Cancer 2006, 95:374-377

5. Gnarra JR, Duan DR, Weng Y, Humphrey JS, Chen DY, Lee S, Pause A, Dudley CF, Latif F, Kuzmin I, Schmidt L, Duh FM, Stackhouse T, Chen F, Kishida T, Wei MH, Lerman MI, Zbar B, Klausner RD, Linehan WM: Molecular cloning of the von Hippel-Lindau tumor suppressor gene and its role in renal carcinoma. Biochim Biophys Acta 1996, 1242:201-210

6. Richards FM: Molecular pathology of von HippelLindau disease and the VHL tumour suppressor gene. Expert Rev Mol Med 2001, 2001:1-27

7. Banks RE, Tirukonda P, Taylor C, Hornigold N, Astuti D, Cohen D, Maher ER, Stanley AJ, Harnden P, Joyce A, Knowles M, Selby PJ: Genetic and epigenetic analysis of von Hippel-Lindau (VHL) gene alterations and relationship with clinical variables in sporadic renal cancer. Cancer Res 2006, 66:2000-2011

8. Herman JG, Latif F, Weng Y, Lerman MI, Zbar B, Liu S, Samid D, Duan DS, Gnarra JR, Linehan WM, Baylin SB: Silencing of the VHL tumorsuppressor gene by DNA methylation in renal carcinoma. Proc Natl Acad Sci USA 1994, 91:9700-9704

9. Schraml P, Struckmann K, Hatz F, Sonnet S, Kully C, Gasser T, Sauter $\mathrm{G}$, Mihatsch MJ, Moch $\mathrm{H}$ : VHL mutations and their correlation with tumour cell proliferation, microvessel density, and patient prognosis in clear cell renal cell carcinoma. J Pathol 2002, 196:186-193

10. Smits KM, Schouten LJ, van Dijk BA, Hulsbergen-van de Kaa CA, 
Wouters KA, Oosterwijk E, van Engeland M, van den Brandt PA: Genetic and epigenetic alterations in the von hippel-lindau gene: the influence on renal cancer prognosis. Clin Cancer Res 2008, 14:782-787

11. Hsu DR, Economides AN, Wang X, Eimon PM, Harland RM: The Xenopus dorsalizing factor Gremlin identifies a novel family of secreted proteins that antagonize BMP activities. Mol Cell 1998 1:673-683

12. Topol LZ, Marx M, Laugier D, Bogdanova NN, Boubnov NV, Clausen PA, Calothy G, Blair DG: Identification of drm, a novel gene whose expression is suppressed in transformed cells and which can inhibit growth of normal but not transformed cells in culture. Mol Cell Biol 1997, 17:4801-4810

13. Topol LZ, Bardot B, Zhang Q, Resau J, Huillard E, Marx M, Calothy G, Blair DG: Biosynthesis, post-translation modification, and functional characterization of Drm/Gremlin. J Biol Chem 2000, 275:8785-8793

14. Hogan BL: Bone morphogenetic proteins: multifunctional regulators of vertebrate development. Genes Dev 1996, 10:1580-1594

15. Miyazaki Y, Oshima K, Fogo A, Hogan BL, Ichikawa I: Bone morphogenetic protein 4 regulates the budding site and elongation of the mouse ureter. J Clin Invest 2000, 105:863-873

16. Miyazaki Y, Oshima K, Fogo A, Ichikawa I: Evidence that bone morphogenetic protein 4 has multiple biological functions during kidney and urinary tract development. Kidney Int 2003, 63:835-844

17. Dudley AT, Lyons KM, Robertson EJ: A requirement for bone morphogenetic protein-7 during development of the mammalian kidney and eye. Genes Dev 1995, 9:2795-2807

18. Luo G, Hofmann C, Bronckers AL, Sohocki M, Bradley A, Karsenty G: BMP-7 is an inducer of nephrogenesis, and is also required for eye development and skeletal patterning. Genes Dev 1995, 9:2808-2820

19. McMahon R, Murphy M, Clarkson M, Taal M, Mackenzie HS, Godson C, Martin F, Brady HR: IHG-2, a mesangial cell gene induced by high glucose, is human gremlin. Regulation by extracellular glucose concentration, cyclic mechanical strain, and transforming growth factorbeta1. J Biol Chem 2000, 275:9901-9904

20. Michos O, Panman L, Vintersten K, Beier K, Zeller R, Zuniga A: Gremlin-mediated BMP antagonism induces the epithelial-mesenchymal feedback signaling controlling metanephric kidney and limb organogenesis. Development 2004, 131:3401-3410

21. Khokha MK, Hsu D, Brunet LJ, Dionne MS, Harland RM: Gremlin is the BMP antagonist required for maintenance of Shh and Fgf signals during limb patterning. Nat Genet 2003, 34:303-307

22. Topol LZ, Modi WS, Koochekpour S, Blair DG: DRM/GREMLIN (CKTSF1B1) maps to human chromosome 15 and is highly expressed in adult and fetal brain. Cytogenet. Cell Genet 2000, 89:79-84

23. Stabile H, Mitola S, Moroni E, Belleri M, Nicoli S, Coltrini D, Peri F, Pessi A, Orsatti L, Talamo F, Castronovo V, Waltregny D, Cotelli F, Ribatti D, Presta M: Bone morphogenic protein antagonist Drm/gremlin is a novel proangiogenic factor. Blood 2007, 109:1834-1840

24. Lee TI, Jenner RG, Boyer LA, Guenther MG, Levine SS, Kumar RM, Chevalier B, Johnstone SE, Cole MF, Isono K, Koseki H, Fuchikami T, Abe K, Murray HL, Zucker JP, Yuan B, Bell GW, Herbolsheimer E, Hannett NM, Sun K, Odom DT, Otte AP, Volkert TL, Bartel DP, Melton DA, Gifford DK, Jaenisch R, Young RA: Control of developmental regulators by Polycomb in human embryonic stem cells. Cell 2006, 125:301-313

25. Widschwendter M, Fiegl H, Egle D, Mueller-Holzner E, Spizzo G, Marth C, Weisenberger DJ, Campan M, Young J, Jacobs I, Laird PW: Epigenetic stem cell signature in cancer. Nat Genet 2007, 39:157-158

26. Yamashita S, Tsujino Y, Moriguchi K, Tatematsu M, Ushijima T: Chemical genomic screening for methylation-silenced genes in gastric cancer cell lines using 5-aza-2'-deoxycytidine treatment and oligonucleotide microarray. Cancer Sci 2006, 97:64-71

27. Suzuki M, Shigematsu H, Shames DS, Sunaga N, Takahashi T, Shivapurkar N, lizasa T, Frenkel EP, Minna JD, Fujisawa T, Gazdar AF: DNA methylation-associated inactivation of TGFbeta-related genes DRM/ Gremlin. RUNX3, and HPP1 in human cancers. Br J Cancer 2005, 93:1029-1037

28. van den Brandt PA, Goldbohm RA, van't Veer P, Volovics A, Hermus RJ, Sturmans F: A large-scale prospective cohort study on diet and cancer in The Netherlands. J Clin Epidemiol 1990, 43:285-295

29. van Houwelingen KP, van Dijk BA, Hulsbergen-van de Kaa CA, Schouten LJ, Gorissen HJ, Schalken JA, van den Brandt PA, Oosterwijk E: Prevalence of von Hippel-Lindau gene mutations in sporadic renal cell carcinoma: results from The Netherlands cohort study. BMC Cancer 2005, 5:57

30. Derks S, Lentjes MH, Hellebrekers DM, de Bruine AP, Herman JG, van Engeland M: Methylation-specific PCR unraveled. Cell Oncol 2004, 26:291-299

31. Herman JG, Graff JR, Myohanen S, Nelkin BD, Baylin SB: Methylation-specific PCR: a novel PCR assay for methylation status of CpG islands. Proc Natl Acad Sci USA 1996, 93:9821-9826

32. van Engeland M, Roemen GM, Brink M, Pachen MM, Weijenberg MP, de Bruine AP, Arends JW, van den Brandt PA, de Goeij AF, Herman JG: K-ras mutations and RASSF1A promoter methylation in colorectal cancer. Oncogene 2002, 21:3792-3795

33. Baldewijns MM, Thijssen VL, Van den Eynden GG, Van Laere SJ, Bluekens AM, Roskams T, van Poppel H, De Bruine AP, Griffioen AW, Vermeulen PB: High-grade clear cell renal cell carcinoma has a higher angiogenic activity than low-grade renal cell carcinoma based on histomorphological quantification and qRT-PCR mRNA expression profile. Br J Cancer 2007, 96:1888-1895

34. Van den Eynden GG, Van der Auwera I, Van Laere SJ, Colpaert CG Turley $H$, Harris AL, van Dam P, Dirix LY, Vermeulen PB, Van Marck EA: Angiogenesis and hypoxia in lymph node metastases is predicted by the angiogenesis and hypoxia in the primary tumour in patients with breast cancer. Br J Cancer 2005, 93:1128-1136

35. Deng G, Peng E, Gum J, Terdiman J, Sleisenger M, Kim YS: Methylation of hMLH1 promoter correlates with the gene silencing with a region-specific manner in colorectal cancer. Br J Cancer 2002, 86:574-579

36. Baldewijns MM, van Vlodrop IJ, Schouten LJ, Soetekouw PM, de Bruine AP, van Engeland M: Genetics and epigenetics of renal cell cancer. Biochim Biophys Acta 2008, 1785:133-155

37. Langenfeld EM, Langenfeld J: Bone morphogenetic protein-2 stimulates angiogenesis in developing tumors. Mol Cancer Res 2004 2:141-149

38. Rothhammer T, Bataille F, Spruss T, Eissner G, Bosserhoff AK: Functional implication of BMP4 expression on angiogenesis in malignant melanoma. Oncogene 2007, 26:4158-4170

39. Raida M, Clement JH, Leek RD, Ameri K, Bicknell R, Niederwieser D, Harris AL: Bone morphogenetic protein 2 (BMP-2) and induction of tumor angiogenesis. J Cancer Res Clin Oncol 2005, 131:741-750

40. Maciel TT, Melo RS, Schor N, Campos AH: Gremlin promotes vascular smooth muscle cell proliferation and migration. J Mol Cell Cardiol 2008, 44:370-379

41. Blish KR, Wang W, Willingham MC, Du W, Birse CE, Krishnan SR, Brown JC, Hawkins GA, Garvin AJ, D'Agostino RB Jr, Torti FM, Torti SV: A human bone morphogenetic protein antagonist is down-regulated in renal cancer. Mol Biol Cell 2008, 19:457-464

42. Chen B, Athanasiou M, Gu Q, Blair DG: Drm/Gremlin transcriptionally activates p21(Cip1) via a novel mechanism and inhibits neoplastic transformation. Biochem Biophys Res Commun 2002, 295:1135-1141

43. Alarmo EL, Rauta J, Kauraniemi P, Karhu R, Kuukasjarvi T, Kallioniemi A: Bone morphogenetic protein 7 is widely overexpressed in primary breast cancer. Genes Chromosomes Cancer 2006, 45:411-419

44. Hsu MY, Rovinsky S, Penmatcha S, Herlyn M, Muirhead D: Bone morphogenetic proteins in melanoma: angel or devil? Cancer Metastasis Rev 2005, 24:251-263

45. Miyazaki H, Watabe T, Kitamura T, Miyazono K: BMP signals inhibit proliferation and in vivo tumor growth of androgen-insensitive prostate carcinoma cells. Oncogene 2004, 23:9326-9335

46. Franzen A, Heldin NE: BMP-7-induced cell cycle arrest of anaplastic thyroid carcinoma cells via p21(CIP1) and p27(KIP1). Biochem Biophys Res Commun 2001, 285:773-781

47. Ghosh-Choudhury N, Woodruff K, Qi W, Celeste A, Abboud SL, Ghosh Choudhury G: Bone morphogenetic protein-2 blocks MDA MB 231 human breast cancer cell proliferation by inhibiting cyclin-dependent kinase-mediated retinoblastoma protein phosphorylation. Biochem Biophys Res Commun 2000, 272:705-711

48. Haudenschild DR, Palmer SM, Moseley TA, You Z, Reddi AH: Bone morphogenetic protein (BMP)-6 signaling and BMP antagonist nog gin in prostate cancer. Cancer Res 2004, 64:8276-8284

49. He XC, Zhang J, Tong WG, Tawfik O, Ross J, Scoville DH, Tian Q, Zeng X, He X, Wiedemann LM, Mishina Y, Li L: BMP signaling inhibits intestinal stem cell self-renewal through suppression of Wnt-betacatenin signaling. Nat Genet 2004, 36:1117-1121

50. Pardali K, Kowanetz M, Heldin CH, Moustakas A: Smad pathway-spe- 
cific transcriptional regulation of the cell cycle inhibitor p21(WAF1/Cip1). J Cell Physiol 2005, 204:260-272

51. Vousden $\mathrm{KH}$ : Activation of the p53 tumor suppressor protein. Biochim Biophys Acta 2002, 1602:47-59

52. Chen WD, Han ZJ, Skoletsky J, Olson J, Sah J, Myeroff L, Platzer P, Lu S, Dawson D, Willis J, Pretlow TP, Lutterbaugh J, Kasturi L, Willson JK, Rao JS, Shuber A, Markowitz SD: Detection in fecal DNA of colon cancer-specific methylation of the nonexpressed vimentin gene. J Natl Cancer Inst 2005, 97:1124-1132

53. Dolan V, Murphy M, Sadlier D, Lappin D, Doran P, Godson C, Martin F, O'Meara Y, Schmid H, Henger A, Kretzler M, Droguett A, Mezzano S, Brady HR: Expression of gremlin, a bone morphogenetic protein antagonist, in human diabetic nephropathy. Am J Kidney Dis 2005, 45:1034-1039

54. Mezzano S, Droguett A, Burgos ME, Aros C, Ardiles L, Flores C, Carpio D, Carvajal G, Ruiz-Ortega M, Egido J: Expression of gremlin, a bone morphogenetic protein antagonist, in glomerular crescents of pauci-immune glomerulonephritis. Nephrol Dial Transplant 2007, 22:1882-1890
55. Namkoong H, Shin SM, Kim HK, Ha SA, Cho GW, Hur SY, Kim TE, Kim $\mathrm{JW}$ : The bone morphogenetic protein antagonist gremlin 1 is overexpressed in human cancers and interacts with YWHAH protein. BMC Cancer 2006, 6:74

56. Sneddon JB, Zhen HH, Montgomery K, van de Rijn M, Tward AD, West R, Gladstone H, Chang HY, Morganroth GS, Oro AE, Brown PO: Bone morphogenetic protein antagonist gremlin 1 is widely expressed by cancer-associated stromal cells and can promote tumor cell proliferation. Proc Natl Acad Sci USA 2006, 103: 14842-14847

57. Lappin DW, McMahon R, Murphy M, Brady HR: Gremlin: an example of the re-emergence of developmental programmes in diabetic nephropathy. Nephrol Dial Transplant 2002, 17 Suppl 9:65-67

58. Pearce JJ, Penny G, Rossant J: A mouse cerberus/Dan-related gene family. Dev Biol 1999, 209:98-110

59. Sun J, Zhuang FF, Mullersman JE, Chen H, Robertson EJ, Warburton D, Liu YH, Shi W: BMP4 activation and secretion are negatively regulated by an intracellular gremlin-BMP4 interaction. J Biol Chem 2006, 281:29349-29356 